\title{
A Dependence Level and Regional Contributions Effect on Income Level and Its Impact: A Case of Public Life Changes Patterns Kandri Agro Tourism Village, Gunung Pati Semarang
}

\author{
Rudi PrasetyoArdi ${ }^{\# 1}$, Syaiful Bakhri ${ }^{\# 2}$, Bambang Dwiloka ${ }^{* 3}$, Sugeng Wahyudi ${ }^{\# 4}$

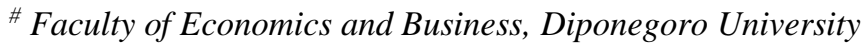 \\ Semarang, Indonesia \\ ${ }^{1}$ spider_struggle@yahoo.co.id \\ Faculty of Animal and Agriculture, Diponegoro University \\ Semarang, Indonesia
}

\begin{abstract}
Kandri Village Gunung Pati, Semarang which has been designated as an area of agro tourism is one of the places for vacation. The research aimed to study the effect and the relationship between the level of dependency and contribution of the agro tourism activity toward public's income level and its impact on the pattern of changes around Kandri agro-tourism village of Gunung Pati Semarang.The research used survey method and the quantitative analysis used Path Analysis. The results showed that the dependence level of Kandri agro-tourism village was significant on income's level Kandri Village, the dependence level of Kandri agro-tourism village was significant on life changes pattern, the contribution of Kandri agro-tourism village was significant on public's income level, the contribution of Kandri agro-tourism village was not significant on the life changes pattern, mean while the income level was significant the life changes pattern. It can be concluded that the dependence level of Kandri village was significant on income levels and the pattern of life changes, Kandri village contribution was significant in the level of income but has been unable to improve the pattern of change in their life. Public income was not being much affected by their attraction Kandri village.
\end{abstract}

Keywords - Dependency Level, Regional Contribution, Income Level, Life Changes Pattern, Kandri Village

\section{INTRODUCTION}

The development of agro-tourism business is still proclaimed by the government for the establishment of agro tourism by determining the areas of rural areas and potential to be established as a tourist status, which is expected with the determination of the village as a tourist village area will be one of the containers for the preservation of nature awake.

Tourism village is a rural area that offers a whole atmosphere that reflects the authenticity of the countryside, both in terms of social culture, customs, daily life, traditional architecture, spatial structure of the village and has the potential to development a various components of tourism such as attractions, eating, drinking, souvenirs, lodging and other tourist needs [1].

One important aspect that needs to get the attention of all concerned is the element of the local community. The development of agro-tourism can improve the economic downturn of the community and open access to infrastructure such as the road to the tourist area that will be the way for the community around to achieve prosperity. Agro tourism is expected to grow later the community can come to feel and contribute directly to the development of the region and freed independently.

The impact of improving human resources can be attributed to the need for increased personnel to influence the improvement of the human resource qualifications assigned to occupy an employment. The linkages between agro-tourism development and regional development include economic, social and economic infrastructure of the community ([2].

Kandri Village Area Gunung Pati Sub-district, Semarang City which has been designated as agro tourism area is one of choice place to spend vacation time. Agro-tourism related activities include the training of rice cultivation, fish farming and cooking class by taking all materials from the fields owned by the available population. The 
activities contained in Kandri Village agro tourism are managed jointly by farmer groups.

This research is expected to be an evaluation material about the development of Kandri Village area as an agro tourism object in order to improve in the economic sector of the surrounding community as well as information material for the government in formulating the management policy of Agro tourism area that is siding with the public interest.

\section{LITERATURE REVIEW}

\section{A. Agro Industry}

Agro tourism is one of the terms used by the community to describe rural tourism, in addition to farm tourism, soft tourism and ecotourism. Agrotourism is one of potential tourism activities to be developed with community-based development approach. The approach is aimed at increasing people's income, providing employment and also contributing to conservation awareness raising. Increased public incomes and employment are made through product and service activities related to agro-tourism [3].

The development of the tourism industry, especially agro-tourism, aims to give and increase the income of local communities. The agro-tourism development efforts consist of choosing strategic locations, providing good services, improving supporting facilities, infrastructure facilities and infrastructure improvements, safeguarding the security and safety of tourists and preserving the environment [4]. Tourism development is implemented by optimizing harmonious, harmonious and integrated resources through a comprehensive approach covering physical, economic, social, cultural and environmental aspects for sustainable development [5].

The development of agro tourism as one of the potential tourism business in Indonesia based on the concept of agriculture in the broad sense is supported by the geographic position of the equator and the various natural, biological and cultural conditions. Efforts to increase people's incomes should remain within the framework of development that ensures the conservation of natural resources. The development of agroindustry and agro-tourism should be further improved in rural areas that are at the same time directed to overcome unemployment problems, in order to absorb the labor surplus of agricultural sector and poverty alleviation [6].

The tourism industry involves several sectors such as the economic, social, cultural, political, security, and environmental sectors that together produce the products of tourism services required by tourists. So, it can be said that tourism is a social phenomenon, economy, culture, psychology and geography [7]. Suyanti [8] argues that tourists are no longer just simply enjoy the natural beauty of tourist attractions with all the facilities of tourism. Nowadays many tourists who also want to enjoy the flexibility of travel by way of direct interaction with the environment and local communities. This change encourages the emergence of the concept of rural tourism which is marked by the emergence of tourist villages in various provinces in Indonesia.

\section{B. Tourism Village}

Tourism village is a rural area that offers a whole atmosphere that reflects the authenticity of the countryside, both in terms of social culture, customs, daily life, traditional architecture, spatial structure of the village and has the potential to develop various components of tourism such as attractions, eating, drinking, souvenirs, lodging and other tourist needs [9]. According to [10], tourist village is a village that has unique potential and unique tourist attraction, either in the form of physical characteristic of rural natural environment and socio-cultural life of society, which is managed and packed in an interesting and natural way with the development of supporting facilities in an environmental harmonious and good management and well planned so ready to receive and drive tourist visits to the village. The eco-tourism activities within the tourist village can improve the welfare and empowerment of the local community. Tourist village is defined by [11] is a form of environment that has special characteristics, both natural and cultural in accordance with the demands of tourists, where they can enjoy knowing, living and learning the uniqueness of the village with all its charm. 


\section{Village Tourism Development Program}

In the opinion of [12] the development of sustainable tourism activities is a process and system of tourism development that can ensure the sustainability or existence of natural resources and socio-cultural life and provide economic benefits to future generations. Indicators that can be derived from sustainable characteristics include the environment. The tourism industry should be sensitive to environmental degradation such as waste pollution, garbage accumulation, and landscape damage caused by deforestation, inappropriate buildings and architecture, and unfriendly citizens' attitudes. Environmental aspects emphasize ecosystem and biodiversity conservation, waste management, land use, water resources conservation, atmospheric protection, and minimization of noise and visual disturbance.

According to [13], in order to achieve the development effort as an ecotourism object, it is important to involve local people in ecotourism activities, support of local government policy in supporting ecotourism activities about tourism objects, good management and design in accordance with the criterion of sustainability environment and in accordance with the carrying capacity of ODTWA (Nature Tourism Objects and Attraction), so that a plan that takes into account environmental sustainability, cultural sustainability, social sustainability and economic sustainability. According to [14], The fundamental limiting factor in determining the main principles of ecotourism is in the environment, society, education and experience, sustainability and management.

\section{Local Community Impacts and Opportunities}

Society is a collection of individuals who are living together as a big and needy unity, fulfilling the same characteristics as a group. The community around the tourist object is the people who live in the area around a tourist attraction, which has a livelihood as food traders, farmers, parking workers and others [15].

A development is said to be community oriented if the development is able to maintain three main elements of development consisting of implementing organizations development, development programs and community. The opportunity to obtain from the impact of the development of these attractions will be more widespread. Therefore, in the implementation of a sustainable tourism strategy by prioritizing the community, in the long term it is expected that regional tourism sector can provide benefits [16].

The socio-economic condition of the society that occurs around the tourism object is the interaction between the tourists and the society as a result of the development of tourism in an area that influences the condition of the society with the indicator that there are changes of work and income, the pattern of division of labor, job opportunity and effort [17]. The development of community-based tourism activities that are closely linked to the elements and practices of local community participation in every phase of tourism development in a region, the phases of regional development planning and ideas, the phases of physical development as well as the commercialization and development of tourist areas.

\section{E. Patterns of Community Life}

People's lifestyles are not only about educational employment and family life, but also include the organization of social society, ceremonies and prevailing customs and religious life, but in a society or village there are several patterns of life. Villagers in a village are occupied by the peasants who are their main livelihood in meeting their daily needs and partly for the social good. A change that occurs in society is not solely for progress but can also lead to a setback. Sometimes the changes that occur too quickly will also have an impact on the community in which people experience culture shock in their daily lives [18].

Social change is also often referred to as social cultural change, this can happen because in general man himself is a social creature that has a culture and in social changes that occur indirectly also change the culture owned by the human, then expanded into society and finally the community also experienced a change both in terms of social and cultural. Three factors that can influence social change are the work pressure in society, the effectiveness of communication and changes in the natural environment. The causes of cultural change 
are changes in the community environment, new discoveries, and contact with other cultures.

\section{MATERIALS AND METHODS}

This research was conducted in Kandri Village, GunungPatiSubdistrict, Semarang City on the grounds that the village has been designated as tourism village by Semarang City Government since 2012. The method used in this research is survey method with quantitative analysis using path analysis or Path Analysis. Selection of research sampling was done randomly through the availability of data and information by using 100 respondents.

Primary data obtained from the questionnaire distributed to the respondents ie the community around the Village Kandri, District of Mount Pati, Semarang City. Secondary data was obtained from the Department of Culture and Tourism of Semarang City and Central Bureau of Statistics (BPS) Central Java. Scale measurement of indicators in this study using Likert scale, ie starting from the smallest means very not agree given the value / score 1 (one) to the greatest value is strongly agree given the score / score 5 (five).

This research was analyzed by using descriptive statistical analysis procedure that is analysis by using tables, graphs, diagrams, average to describe the object under study. Qualitative descriptive analysis is used to get an explanation about the socio-economic problems of the community around agro tourism Kandri Village. Inferential statistical analysis is the analysis conducted to test the research hypothesis. In this study used path analysis to determine the influence of the level of dependence of the community on the level of income and its impact on the pattern of changes in people's lives.

\section{RESULTS AND DISCUSSION}

\section{A. The Geographical Situation of Kandri Village}

Kandri Tourism Village is located in GunungPatiSubdistrict, Semarang City. Kandri village has an area of 357,848 ha, located at an altitude of $349 \mathrm{~m}$ above sea level (asl) which is classified in highland areas and has a rainfall of 810 $\mathrm{mm} /$ year and has an average air temperature of $28^{\circ} \mathrm{C}$. The geographical boundary of Kandri Village covers the northern borders of Sadeng Village, the south is bordered by KelurahanCepoko, the west is adjacent to JatirejoSubdistrict and Regency of Nongkosawit and Pongangan in the east. Kandri Village is divided into $4 \mathrm{RW}$ and $26 \mathrm{RT}$. Kandri village there are $2 \mathrm{SD}$ and there is 1 kindergarten. Kandri Village there Reservoir for irrigation facilities named Jatibarang Reservoir area of $80 \mathrm{Ha}$ and there is a Goa called Goa Kreo which serve as a tourist attraction by the local community.

Kandri village distance from the district government center is 3.5 kilometers. The distance from the provincial capital is 16 kilometers. Kandri Village has 3 parks with an area of $16 \mathrm{~m} 2$. The existing road conditions in the village of Kandri is good enough and paved. The transportation used in Kandri Village is in the form of public transportation and private vehicle. Access roads traversed by indigenous people and tourists can be skipped in both directions.

\section{B. The Influence of Village Tourism Addiction Level to Community Income Level}

Kandri Village with various activities that make it as tourist village significantly influence the income level of the community $(\mathrm{P}<0,05)$. This can be because the community participates in the existing activities. The development of Kandri Village as a tourist village as a whole gives a good impact for the community. Environment in the village of Kandri also more awake cleanliness and keasriannya. People are not a few who open new business places such as opening a place to eat and also open a homestay to be a temporary residence for visitors who want to spend the night enjoying the beauty of Kandri Tourism Village. Citizens are also willing to be a tour guide to be invited to tour around Kandri Tourism Village with all its activities. Wihasta and Prakoso [19] argue that the availability of adequate facilities and infrastructures can support the development of tourist villages so that the community and stakeholders can participate and contribute and feel the good impacts of tourism village development.

\section{The Effect of Income Level of Society on The Pattern of Change of Life}

The level of community dependence on Kandri tourism area has significant effect on life changing 
pattern $(\mathrm{P}<0,05)$. People began to rely on life with the Village Tourism Kandri little by little began to change his lifestyle. Communities who were initially more passive in communicating now tend to be more active and more friendly. Martono [20] argues that lifestyle changes is actually a life style (lifestyle) that follows the pattern of development of the era, with all forms of science and technology progress. Development and change can not be dammed by anything. This is what happens in human civilization. This is certainly inevitable. Man can not escape from any advances in science and technology. Humans are basically required to be able to adapt to anyone, anywhere, anytime and under any circumstances.

\section{The Effect of Income Level of Society on The Pattern of Change of Life}

Based on the table, it can be seen that the income level obtained by Kandri villagers significantly influence the pattern of life change $(\mathrm{P}<0.05)$. This is because with Kandri Village danya make people get additional income so that people who open a business or trade provide a variety of purposes needed visitors. People make various souvenirs to be made souvenirs. The development of natural tourism activities should be able to create a solid foundation of work. Appropriate direction towards the target and develop opportunities equally for the benefit of the community to meet the needs of employment and increase community incomes [21]. Increased public incomes and employment are made through product and service activities related to agro-tourism[22].

\section{E. The Influence of Village Tourism Contribution to Community Income Level}

Based on the table, it can be seen that there is a significant relationship between the contribution of Kandri Tourism Village area to the income level of the community $(\mathrm{P}<0.05)$. This is because with the Village Tourism Kandri community no longer difficulty in making a living because it can make their own business and citizens the opportunity to trade and then sold to visitors who visit the village. The community also helped maintain the security and comfort of the village so as to make visitors want to linger to be in the sesa. The facilities and infrastructure are getting better and the roads passed can be easily passed. Manuabu [23] states that the planning of the development of a region and the development of tourism objects are expected to be planned carefully with attention to environmental sustainability. In the absence of planning may lead to undesirable developments such as inappropriate use of spatial planning, environmental degradation, the development of unbalanced sectors of activities and the creation of social and other problems.

\section{F. The Influence of Dependence on Pattern of Life Changes of Kandri Village People}

Based on the table, it can be seen that the level of community dependence on Kandri Tourism Village has significant effect on life changing pattern $(\mathrm{P}$ $<0,05)$. People began to rely on life with the Village Tourism Kandri little by little began to change his lifestyle. Communities who were initially more passive in communicating now tend to be more active and more friendly. Martono (2012)[24] argues that lifestyle changes is actually a life style (lifestyle) that follows the pattern of development of the era, with all forms of science and technology progress. Development and change can not be dammed by anything. This is what happens in human civilization. This is certainly inevitable. Man can not escape from any advances in science and technology. Humans are basically required to be able to adapt to anyone, anywhere, anytime and under any circumstances.

\section{G. The Effect of Area Contribution to Life Change Patterns}

Based on the Table, it can be seen that the contribution of the region has not been able to directly affect the pattern of life change of the village of Kandri (P>0,05). This is due to the contribution given by the Village Tourism Kandri the number is still relatively small so it has not been able to influence changes in community lifestyle. According[25] changes that exist include elements of cultural material and immateril by emphasizing that the great influence of the immaterial elements. Judging from the demands of the stability of life of social change experienced by society is a natural thing. In contrast, people who do not dare to make changes will not be able to serve the demands and dynamics of the ever-evolving members. 
H. Relationship between Dependency Level, Income Level on Life Change Patterns

This means that Kandri Tourism Village is directly able to influence the changing pattern of community life around Kandri Village. Dependency level either directly or indirectly can influence pattern of life change of society around Kandri Village. Lopez-Guzman et al. [26], argues that the development of community-based tourism activities can create jobs and grow welfare and increase incomes for participating communities. As a tourist destination, tourist villagers should have a perception that the inhabitants are friendly to visitors as well as the diversity of ecological wealth. Community involvement and support are important factors that determine the success or failure of the development of community-based tourism activities. Efforts to increase people's incomes should remain within the framework of development that ensures the conservation of natural resources. The development of agro-industry and agro-tourism should be further improved in rural areas that are at the same time directed to overcome unemployment problems, in order to absorb the excess labor of agriculture and poverty alleviation [27]. Ekokonomi activities within the tourist village can improve the welfare and empowerment of local communities [28].

\section{CONCLUSION}

The result of this research can be concluded that the dependency of Kandri Village area influence to income level of Kandri Village, Kandri Village dependency influence to changing pattern of life of Kandri Village, Kandri Village contribution influence to income level of Kandri Village, to the pattern of life change of Kandri Village and income level have an effect on to change pattern of life of Kandri Village community. The dependency of Kandri Village area has an effect on income level and life changing pattern, contribution of kawsasan influence to income level but not yet able to improve pattern of life change. The income of the community has not been much affected by the existence of Kandri Village tourist attraction.

\section{REFERENCES}

[1] Agus, M.P. (2006). Konsep Desa Wisata. Universitas Triatmamulya.
[2] Islami, R.C., D.W. Adrianto, and K.E. Sari. (2013). KajianDampakSosialEkonomiPengembanganKawasanWisataTerhadap KondisiMasyarakat. Planning for Urban Region and Environment Journal. Volume 2 (3).: 243-252.

[3] Aref, F.danS.S.Gill. (2009). Rural tourism development through rural cooperatives,Marsland Press, New York. Nature and Sci. 7 (10): 21- 25.

[4] Arifin, H.S., A. Munandar., and H.A.S. Nurhayati. (2008) Harmonisasi Pembangunan pertanian Berbasis Daerah Aliran Sungai Pada Lanskap Desa Kota Kawasan Bogor Puncak Cianjur (Bopuncur), Direktorat Jendral Pendidikan Tinggi Departemen Pendidikan Nasional, InstitutPertanian Bogor.

[5] Dewanti, A.N and E.B. Santoso. (2012). Penentuan Alternatif Lokasi Pengembangan Kawasan Agroindustri Berbasis Komoditas Pertanian Unggulan di Kabupaten Lamongan. J Teknik (1): 33-37.

[6] Djamudin, A., M. Fauzi., H.S. Arifindan Sukardi. (2012). Studi Pengembangan Agroindustri dan Agrowisata Terpadu di Daerah Aliran Sungai (DAS) Kali Bekasi Kabupaten Bogor. Jurnal Teknologi Industri Pertanian. 22 (3):151-163.

[7] Subadra, I.N. dan N.M. Nadra. (2006). Dampak Ekonomi, SosialBudaya dan Lingkungan Pengembangan desa Wisata di JatiluwihTabanan. Jurnal Manajemen Pariwisata. Volume 5(1): 46-64.

[8] Suyanti, D.W. (2013). Potensi Desa Melalui Pariwisata Pedesaan Jurnal Ekonomi dan Bisnis. Volume 12(1): 33-36.

[9] Agus, M.P. (2006). Konsep Desa Wisata. Universitas Triatmamulya.

[10] Subadra, I.N. dan N.M. Nadra. (2006). Dampak Ekonomi, SosialBudaya dan Lingkungan Pengembangan desa Wisata di JatiluwihTabanan. Jurnal Manajemen Pariwisata. Volume 5(1): 46-64.

[11] Suyanti, D.W. (2013). Potensi Desa Melalui Pariwisata Pedesaan. Jurnal Ekonomi dan Bisnis. Volume 12(1): 33-36.

[12] Subadra, I.N. dan N.M. Nadra. (2006). Dampak Ekonomi, SosialBudaya dan Lingkungan Pengembangan Desa Wisata di JatiluwihTabanan. Jurnal Manajemen Pariwisata. Volume 5(1): 46-64.

[13] Latupapua, Y. (2008). Studi Potensi Kawasan dan Pengembangan Ekowisata di Tual Kabupaten Maluku Tenggara. Fakultas Pertanian Universitas Patimura Ambon. Jurnal Ichsan Gorontalo, Volume 3(1): 66-71.

[14] Permatasari, B.R., A.M. Ridjal and A.Soekirno. (2014). Penerapan Konsep Permakultur dengan Pendekatan Sosio-Ekologi dalam Membangu Desa Wisata. Jurnal RUAS. Volume 12(1): 91-100.

[15] Mistriani, (2014). Strategi Pengembangan Desa Wisata Berbasis Budaya dan Ekonomi Kreatif serta Dampaknya Terhadap Eknomi Masyarakat di Desa WisataLoram Kulon Kabupaten Kudus. Sekolah Tinggi Ilmu Ekonomi Pariwisata Indonesia, Semarang.

[16] Dyan, T.P. (2006). Dampak Pengembangan Obyek Wisata Lava Tour Desa Kepuharjo Cangkringan Sleman Yogyakarta Terhadap Kondisi Sosial Ekonomi dan Sosial Budaya. Sekolah Tinggi Ilmu Ekonomi Pariwisata Indonesia, Semarang.

[17] Safitra, A.R. and F. Yusman. (2014). Pengaruh Desa Wisata kandr iterhadap Peningkatan Kesejahteraan Masyarakat Kelurahan Kandri Kota Semarang. Jurnal Teknik PWK. Volume 3(4): 908-917.

[18] [Oka, I.M.D. (2010). Potensi Pengembangan Pariwisata Minat Khusus di Desa Pejaten Tabanan. Jurnal Analisis Pariwisata. Vol 10 (1): 24-31.

[19] Wihasta, C.R. dan H.B.S.E. Prakoso. (2012). Perkembangan Desa Wisata Kembang Aram dan dampaknya terhadap Kondisi Sosial Ekonomi Masyarakat Donokerto Kecamatan Turi.

[20] Martono, N. (2012). Sosiologi Perubahan Sosial. Perspektif Klasik Modern, Pos Modern dan Poskolonial. Raja Grafindo, Jakarta.

[21] Oka, I.M.D. (2010). Potensi Pengembangan Pariwisata Minat Khusus di Desa Pejaten Tabanan. Jurnal Analisis Pariwisata. Vol 10 (1): 24-31.

[22] Aref, F.danS.S.Gill. (2009). Rural tourism development through rural cooperatives,Marsland Press, New York. Nature and Sci. 7 (10): 21- 25.

[23] Manuaba, A. (1998). Strategi Pariwisata yang Berdimensi Kerakyatan. Majalah Ilmiah Pariwisata Ps Pariwisata, Universitas Udayana.

[24] Martono, N. (2012). Sosiologi Perubahan Sosial. Perspektif Klasik Modern, Pos Modern dan Poskolonial. Raja Grafindo, Jakarta.

[25] Martono, N. (2012). Sosiologi Perubahan Sosial. Perspektif Klasik Modern, Pos Modern dan Poskolonial. Raja Grafindo, Jakarta.

[26] Lopez-Guzman, T., S. Sanchez-Canizarez., and V.Pavon. (2011). Community-Based Tourism In Developing Countries, a Case Study.Tourismos: an international multidisciplinary Journal of Tourism Volume 6 (1): 69-84. 
[27] Djamudin, A., M.Fauzi., H.S. Arifindan Sukardi. (2012). Studi Pengembangan Agroindustri dan Agrowisata Terpadu di Daerah Aliran Sungai (DAS) Kali Bekasi Kabupaten Bogor. Jurnal Teknologi Industri Pertanian. 22 (3):151-163
[28] Yudiarini, N., K.B. Susrusadan N.W.S. Astiti. (2014). Dampak Pengembangan Agribisnis pada Subak terhadap Pendapatan Rumah Tangga Petani. Jurnal Manajemen Agribisnis. Vol 2 (1). 